\title{
Use of Augmented Reality Methods to Support Legal Conflicts in the Planning Process for Wind Turbines Using the Example of the Landscape Conservation Area "Eulenkopf and Surroundings"
}

\author{
Timo Wundsam, Sascha M. Henninger \\ Department of Physical Geography, University of Kaiserslautern, Kaiserslautern, Germany \\ Email: Timo.Wundsam@ru.uni-kl.de, Sascha.Henninger@ru.uni-kl.de
}

Received 16 July 2014; revised 18 August 2014; accepted 5 September 2014

Copyright (C) 2014 by authors and Scientific Research Publishing Inc.

This work is licensed under the Creative Commons Attribution International License (CC BY).

http://creativecommons.org/licenses/by/4.0/

(c) () Open Access

\section{Abstract}

The world's growing energy demand poses a serious problem. At the same time fossil fuels are finite, which we must work against. Therefore, the Federal Government of Germany has set itself the goal to push forward the use of renewable energy in order to completely do without the generation of nuclear energy by 2023. There are, however, no specific guidelines from the European Directive on the promotion of electricity from renewable energy sources for the internal electricity market regarding how high each share of the different production method should be and, above all, which specific aim should be achieved by the share of wind energy. Nevertheless, it presents a crucial step toward a nuclear phaseout and a concomitant change of course of the Federal Government of Germany in the spring of 2011 regarding the expansion of renewable energy, taking the nuclear catastrophe in Fukushima into account. Using new legal planning approaches, also including the area of Rhineland-Palatinate, opportunities should be provided to make previously protected land available for setting up facilities for the generation of renewable energy. However, it is important to examine the legal situation regarding the installation of these kinds of constructions more detailed, as no general statements can be made. This will be illustrated using the example of the landscape conservation area "Eulenkopf and surrounding area" in the district of Kaiserslautern. The stated goal of the Social Democrat/Green coalition of the federal state government of Rhineland-Palatinate is to considerably expand the generation of electricity from renewable energy sources so that by $\mathbf{2 0 3 0}$ at least the entire electricity demand can be covered by those. Due to the enormous potential of wind power, it is therefore necessary to quintuple its share of electricity generation by 2020, compared to 2011 numbers. In order to achieve the desired political objectives, by 2030 the number of turbines has to be increased to around 2650, 
representing a capacity of $7500 \mathrm{MW}$. This increase gives reason for boundary conditions to manage the generation of wind energy to be adjusted. This is intended to facilitate management and simultaneously minimise negative effects, such as the "sprawling" of wind turbines.

\title{
Keywords
}

\author{
Renewable Energy, Wind Energy, Turbines, Urban Planning, Landscape Conservation Area, \\ Regulation, Laws, Augmented Reality, Public Interest
}

\section{Introduction}

The world's growing energy demand, which is mainly due to increased consumption-which again is due to higher standards of living, increasing mechanization in everyday life as well as due to recreational activities and energy-intensive production processes, poses a serious problem. At the same time fossil fuels are finite, which we must work against. Therefore, the Federal Government of Germany has set itself the goal to push forward the use of renewable energy in order to completely do without the generation of nuclear energy by 2023. Using new legal planning approaches, also including the area of Rhineland-Palatinate, opportunities should be provided to make previously protected land available for setting up facilities for the generation of renewable energy. However, it is important to examine the legal situation regarding the installation of such constructions in more detailed, as no general statements can be made. This will be illustrated using the example of the landscape conservation area "Eulenkopf and surrounding area" in the district of Kaiserslautern.

\section{Problem Statement}

The latest revision of 2012, the German Act on Granting Priority to Renewable Energy Sources (short: EEG (Erneuerbare-Energien-Gesetz)) regulates the preferred supply of electricity from renewable sources. According to §3 EEG, the following renewable energy sources are used for the generation of electricity:

- Hydropower,

- Geothermal energy,

- Energy from biomass, including biogas, biomethane, landfill gas and sewage gas as well as the biodegradable proportion of waste from households and industry, as well as

- Wind energy.

There are, however, no specific guidelines from the European Directive on the promotion of electricity from renewable energy sources for the internal electricity market (Directive 2001/77/EC), regarding how high each share of the different production method should be and, above all, which specific aim should be achieved by the share of wind energy [1]. Nevertheless, it presents a crucial step toward a nuclear phaseout and a concomitant change of course of the Federal Government of Germany in the spring of 2011 regarding the expansion of renewable energy, taking the nuclear catastrophe in Fukushima into account. The catastrophe of Fukushima illustrated the enormous environmental hazard radiation poses both in the generation of nuclear power as well as in the storage of nuclear waste [2]. As a result, the previously agreed on life-span extension of nuclear reactors to an average of twelve year was discarded. By the end of 2022, all nuclear power plants shall be shut down for good [3]. Particular importance is given to wind energy, because, unlike other renewable energy sources, it is able to cover a large energy demand. Thus it shows great potential for expansion.

\subsection{Partial Adjustment of the State Development Programme IV (LEP IV) Regarding Wind Energy Use}

The stated goal of the Social Democrat/Green coalition of the federal state government of Rhineland-Palatinate is to considerably expand the generation of electricity from renewable energy sources so that by 2030 at least the entire electricity demand can be covered by those. Due to the enormous potential of wind power, it is therefore necessary to quintuple its share of electricity generation by 2020, compared to 2011 numbers. In order to achieve this, each region of the federal state is to contribute to the target achievement proportionately, taking 
into account local conditions [4].

In mid-2013, there were about 1300 wind turbines in Rhineland-Palatinate with a total capacity of currently around 2100 megawatts (MW). In order to achieve the desired political objectives, by 2030 the number of turbines has to be increased to around 2650, representing a capacity of 7500 MW [5]. This increase gives reason for boundary conditions to manage the generation of wind energy to be adjusted. This is intended to facilitate management and simultaneously minimise negative effects, such as the "sprawling" of wind turbines. On 11 May 2013, the Partial Adjustment of the State Development Programme IV (Landesen twick lungs programm, or short: LEP IV) came into effect, which states that at least $2 \%$ of the land, and of which at least $2 \%$ must be woodland areas, should be made available for the use of wind energy. Furthermore, it contains revised guidelines regarding the use of wind energy. Herewith, the development of renewable energy is promoted, and at the same time it is aimed to help achieve climate change and energy policy objectives. It must be pointed out that the Partial Adjustment has transferred a large proportion of the responsibility regarding the management of wind energy use to the municipal level. Site selection for wind turbines, with the exception of a few exclusion areas which have been predefined by land use planning, is carried out at regional planning level. This results in a change in planning hierarchy, which limits regional planning in their authority. The implementation of the expansion of wind energy in Rhineland-Palatinate is therefore transferred to the individual municipalities, as the regulation in regions that are outside of certain areas and priority areas is reserved to urban land-use planning in the form of concentration areas [5]. The aim is to give local authorities additional room to manoeuvre with regards to how wind turbines are disclosed on land development plans. This creates an entirely new scope of duties for local authorities, which must be managed both from an expertise as well as a staffing perspective.

The Partial Adjustment has not only led to changes in responsibilities, but it also features fundamental alterations with regards to prerequisites for the sites of wind turbines. For example, landscape conservation areas, certain parts of nature reserves and biosphere reserves as well as Natura 2000 sites are no longer areas that are out of bounds, and can therefore be considered as potential areas for the use of wind turbines. Areas are therefore modified which must be noted both in local land-use plans as well as in regional development plans. This results not only in changes in planning policies but also changes from a nature conservation and natural law point-of-view.

In order to be able to efficiently expand wind energy, when planning suitable sites must be identified and simultaneously unsuitable sites must be excluded. Protection from neighbours, as well as wind conditions are important factors when selecting suitable locations. Nature conservation issues and landscape conservation are also to be taken into account. These include the protection of species, the protection of the landscape, as well as the recreational value of a landscape [6]. Opening up former prohibited areas does not mean that protected areas are overall conferred right to use, however wind energy generation will be described as admissible if it “(...) is compatible with the conservation aim" [5]. The consequence of this is that a large number of individual decisions will be necessary to clarify whether the conservation aim of certain areas will be impaired by the installation of wind turbines in some locations. In addition, as a result of a complete or partial deregulation of certain areas, from a legal point of view it will be possible to implement wind turbines in certain parts of a conservation area.

\subsection{Criticism of the Partial Adjustment of the LEP IV}

The problem of the Partial Adjustment is that in future municipalities are to directly conduct the further expansion of renewable energy rather than it being part of local planning authorities, where it really belongs [7]. According to $\S 35$ BauGB, it will be necessary to come up with a coherent and comprehensible concept, based on the land development plan, in order to achieve special protection status for wind turbine planning outside of the special protection areas and therewith to be able to obtain a regulation. For this purpose a study of the entire municipal area is carried out and it is to provide evidence that the selected sites for wind turbines are suitable with regards to wind conditions, indicating that therefore the so-called "substantial contribution" to the development of renewable energy is met. The criteria used should be transparent and must not be subjectively controlled [7].

Some local authorities feel capable of coping with this task, as they, among other things, have the qualified personnel and the budget necessary to develop such a concept. The reason that other local authorities are showing some resistance is not so much reluctance or indifference. It is rather because the resulting costs for the development of such concepts pose a crucial problem, since these would amount to about $30.000-80.000$ Euros at 
local authority association level, plus similar costs if the adjustment of the land development plan was to be outsourced. The resulting income of the generated wind energy primarily goes towards operators and farmers, and one must be allowed to ask why a local authority association, which often struggles financially itself, should not be the ones benefitting from this [7]. For this reason, the willingness to create such concepts is particularly apparent in regions where more areas are found in which regional planning has given local authorities scope for planning, i.e. scope for control. This is, for example, the case in Western Palatinate [7].

\section{Objective}

The Partial Adjustment of the LEP IV does not contain clear information regarding the questions that have arisen directly from it. In current literature, the deregulation of protected areas for the generation of wind energy is subject of great controversy, and there is no unanimous opinion on it. For that reason, the case example of the landscape conservation area "Eulenkopf and surrounding area" in the district of Kaiserslautern aims to illustrate how best to deal with the "new" planning control of wind turbines, and what risks as well as opportunities for local authorities are associated with the Partial Adjustment of the LEP IV.

\section{Boundary Conditions}

Below, a general outline of the underlying boundary conditions is presented in order to illustrate the problems and the current legal stipulations.

\subsection{Categories of Protected Areas}

Due to the planning management of wind energy generation in areas significant from a nature conservation point-of-view, there are various conflicts between nature conservation and climate protection. Depending on the category of protected area, these two are either contrary to the production of wind energy or can be overcome. Table 1 shows prohibitions and exceptions for the different categories of protected areas.

As this project is in the context of a landscape conservation area within the district of Kaiserslautern, it will be discussed in more detail below.

\subsection{Landscape Conservation Areas}

Landscape Conservation Areas are, according to national law, legally binding appointed areas that hold particular significance for the conservation of nature and landscape [8]. Compared to nature reserves, these larger areas hold fewer restrictions to use, making it a versatile and flexible category of protected area [9].

\section{Legal Background}

The regulation of Landscape Conservation Areas can be found in $\S 36$ of the Federal Law of the Protection of Nature (BNatSchG). Hereby three reasons arise for the need of protection:

Table 1. Overview of prohibitions and exceptions of the considered categories of protected areas [10].

\begin{tabular}{|c|c|c|}
\hline Category & Prohibitions & Exceptions \\
\hline Nature reserve & No changes allowed whatsoever & None, only with special justification \\
\hline Landscape conservation area & $\begin{array}{l}\text { Relative prohibition of changes, } \\
\text { adverse effect on the character of the area }\end{array}$ & $\begin{array}{l}\text { If consistent with conservation aim } \\
\text { and character of the area }\end{array}$ \\
\hline Natura 2000-area & $\begin{array}{l}\text { Potentially inconsistent with } \\
\text { preservation and conservation aim }\end{array}$ & $\begin{array}{l}\text { Consistent with preservation and } \\
\text { conservation aim, depending on } \\
\text { the stipulation of the selected area }\end{array}$ \\
\hline Biosphere reserve & $\begin{array}{l}\text { Depending on the zone, absolute or } \\
\text { relative ban on changes }\end{array}$ & $\begin{array}{l}\text { Depending on zone stipulation of nature } \\
\text { reserve or landscape protection area }\end{array}$ \\
\hline Nature park & $\begin{array}{l}\text { Depending on the zone, absolute or } \\
\text { relative ban on changes }\end{array}$ & $\begin{array}{l}\text { Depending on zone stipulation of nature } \\
\text { reserve or landscape protection area }\end{array}$ \\
\hline
\end{tabular}


1. "To maintain or restore the effectiveness and functionality of the ecosystem or the ability for regeneration and sustainable use of natural resources, including the protection of biotopes and habitats of certain species of wildlife, both fauna and flora,

2. because of the diversity, uniqueness and beauty or because of the special cultural and historic significance of the area or,

3. because of their importance for recreation" [11].

Therefore, landscape conservation areas are usually large sections of the countryside which have satisfied at least one of the three protective features mentioned. Thus landscape areas can be identified that are characterized by human use and also have an importance for nature conservation and landscape management, even though they do not have the prerequisites of a nature reserve [8].

\subsection{Setting up Wind Turbines in Landscape Conservation Areas}

In order to meet the ambitious goals of Rhineland-Palatinate of promoting wind energy in the coming years, pressure is rising in the selection of sites for wind turbines, as more areas will be required. This raises the question to what extent it is possible to set up wind turbines in landscape conservation areas, or whether these areas should be kept clear from such use. Numerous dissentients are arguing that wind turbines have a negative impact on the landscape, which suggests that wind turbines and landscape conservation cannot coincide.

However, areas subject to the conservation status of a landscape conservation area do not enjoy complete protection, but there is a change clause which prohibits actions which, according to § 26 Section 2 BNatSchG, alter the character of the area or run contrary to its special conservation aim. In accordance with $\S 26$ Section 1 No. 1-3 BNatSchG, it is also prohibited to introduce foreign bodies, such as wind turbines, into the area. It is therefore the prevailing opinion that is not possible to derive a general exclusion of wind turbines in landscape conservation areas [12]. In particular cases, it is necessary to review if the installation of wind turbines is consistent with the conservation aim, as the conservation aim and therefore the designation of a landscape conservation area is based on its individual characteristics and qualities [13].

If the sole conservation aim of a landscape conservation area is that of conservation, development or restoration of the ecosystem's productivity and efficiency in accordance with $\S 26$ Section 1 No. 1 Federal Law of the Protection of Nature (\$26 Section 1 No. 1 BNatSchG), it is possible to set up wind turbines but only if it is consistent with the conservation aim [2]. It is of particular importance to ensure that the conservation aim does not go back to wind-sensitive animal species in the area [2].

Changes in the area's character are not permitted either, because the unique identity of the landscape must be preserved. If elements are added which are not in line with the features of the landscape in terms of their dimensions, height, material etc., then they are incompatible with the area [2]. According to Nohl [14], wind turbines are perceived to be "totally inappropriate and foreign bodies to the landscape", which means, that the area would lose its unique character. Scheidler [12] considers the setting up of wind turbines in landscape conservation areas to be an unlawful act. According to 335 Section 3 (1) No. 5 BNatSchG, privileged utilisations are only opposed to the interests of the overall appearance of the landscape, if deformation is to be expected. Impairment is therefore not generally sufficient to counteract the establishment of wind turbines. There is, however, still a ban on impairments in landscape conservation areas, as the area is under particular protection according to the Federal Law of the Protection of Nature §36 Section 2 in conjunction with $\S 36$ Section 1 No. 2 Federal Law of the Protection of Nature (§36 Section 2 BNatSchG combined with §36 Section 1 No. 2 BNatSchG) [12]. Although no general exemption may be granted, there may however be the possibility of individual cases to be issued with an exception or exemption for the construction of wind turbines, according to §67 Federal Law of the Protection of Nature [15] [16]. This can only arise from overriding grounds of public interest, and if arguments for the construction of wind turbines in an individual case outweigh the reasons against it. During consideration, the interest in providing continuous supplies of energy is relevant, although priority of renewable energy over the protection of the environment cannot be derived from this [17]. In such an assessment of individual cases, however, the case-specific grounds must play a crucial role and the result must remain open [17]. In addition, there is the possibility of obtaining the approval for wind turbines in a specific area by changing the regulations of a landscape conservation area. To justify this amendment, authorities must provide objective reasons that make such an amendment necessary, in order to weigh this up against the interests of nature conservation, where the principle of proportionality has to be respected [6]. In accordance with §22 Section 1 (3) of the Federal Law of the 
Protection of Nature, a zoning of protected areas may be carried out, in order to define individual areas within a landscape conservation area in which the construction of wind turbines is permitted. This ensures that the conservation aim, which is not affected by the construction of wind turbines, remains [6] and a partial revocation of landscape conservation areas can be avoided [18].

\section{Landscape Conservation Area "Eulenkopf and Surrounding Area"}

\subsection{Classification}

The landscape conservation area Eulenkopf is located in the north-western district of the independent city of Kaiserslautern and extends over an area of 3550 ha, reaching across the districts of the association of municipalities Weilerbach and Otterbach. The settlements of the municipalities Sulzbach, Frankelbach, Erzenhausen and Eulenbis all lie entirely within the landscape conservation area as Figure 1 shows [19].

The landscape conservation area "Eulenkopf and surroundings area" was provisionally placed under protection in 1963 by the Rhineland-Palatinate rights of nature. On August 30, 1977, the regulation on the landscape conservation area "Eulenkopf and surrounding area" became final. The protected status was due to its characteristic landscape worthy of conservation, in which the typical character of this region is formed by cultivated landscape for agricultural and forestry use. These again are characterised by agriculturally used tablelands, numerous valley cuttings and slopes [21]. Above all, observation points, which allow a panoramic view across large parts of the protected area, are to be emphasised. The municipality Eulenbis can be classed as a well-developed tourist area due to its location on a plateau, resulting in attractive views across the protected area. In addition, it is a designated and recognised tourist destination [22] [23]. It offers numerous cycling and hiking trails, as well as the Eulenkopf tower as a lookout point, all of which are popular tourist attractions.

\subsection{Wind Energy Use and Wind Conditions}

In the district of Kaiserslautern, wind energy is-with about 47\%-the most subsidized form of renewable energy [24]. These figures put the district of Kaiserslautern into eighth place in comparison with other districts, bearing in mind that not all districts exhibit the same regional requirements for the generation of wind energy. According to the Wind Atlas Rhineland-Palatinate, the landscape conservation area "Eulenkopf and surrounding area" exhibits the following wind speeds:

In $100 \mathrm{~m}$ above ground, Figure 2 shows mainly average wind speeds under $5 \mathrm{~m} / \mathrm{s}$ prevail, with slight small scale increases of speeds from 5.4 to $6.0 \mathrm{~m} / \mathrm{s}$. Sporadically measurements are taken of wind speeds up to 6.0 to $6.4 \mathrm{~m} / \mathrm{s}[25]$.

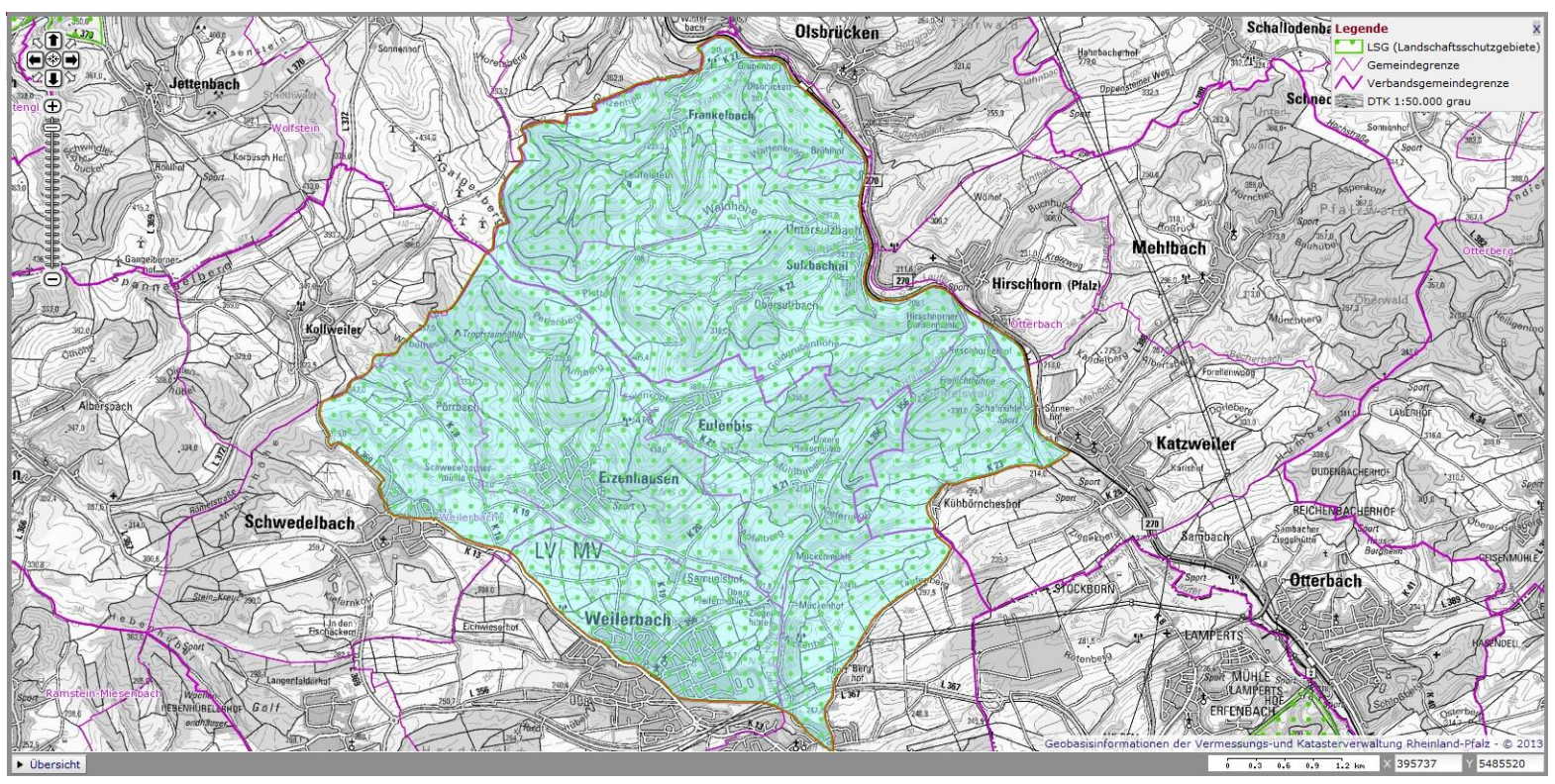

Figure 1. General map of the landscape conservation area “Eulenkopf and surrounding area” [20]. 


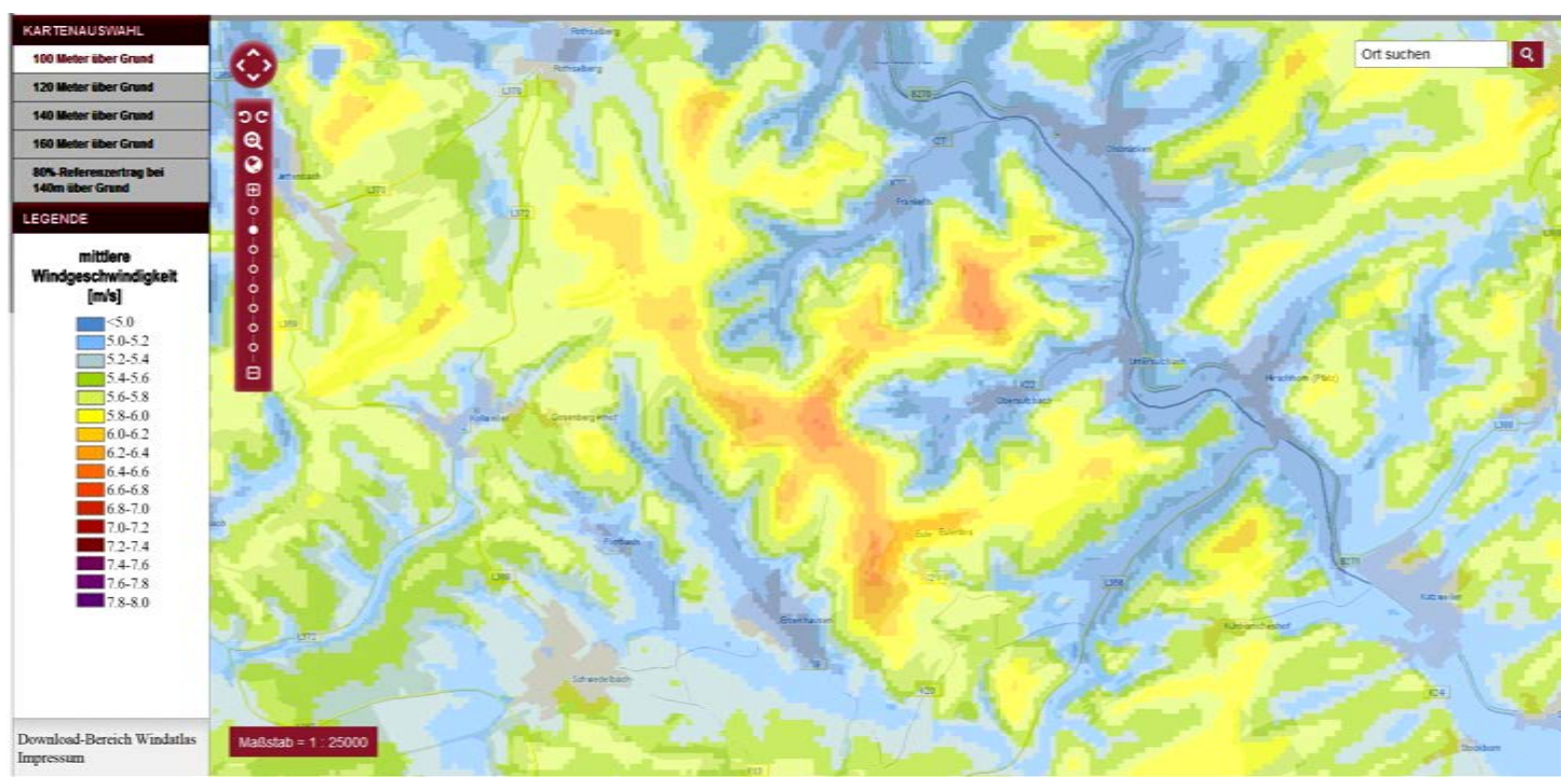

Figure 2. Wind Speed in the landscape conservation area "Eulenkopf and surrounding area" in $100 \mathrm{~m}$ above ground [26].

In $120 \mathrm{~m}$ above ground there are also mainly average wind speeds of 5.4 to $5.6 \mathrm{~m} / \mathrm{s}$. Wind speeds of 6.4 to 6.6 $\mathrm{m} / \mathrm{s}$ occur very rarely [25].

Medium wind speeds from 5.2 to $6.0 \mathrm{~m} / \mathrm{s}$ are expected in $140 \mathrm{~m}$ above ground. Only rarely do wind speeds reach $6.4-6.8 \mathrm{~m} / \mathrm{s}$ [25].

In $160 \mathrm{~m}$ above the ground, wind speeds range from 5.8 to $6.0 \mathrm{~m} / \mathrm{s}$, although in individual areas wind speeds of 6.4 to $6.8 \mathrm{~m} / \mathrm{s}$ can be achieved [25].

\subsection{Statements from the Landscape Regulation}

Legal regulation of the protected area defines the conservation aims of the characteristic landscape as quality of landscape, recreation as well as the protection of natural resources in accordance with § 3a-c of the landscape conservation regulation (LSchVO) Eulenkopf. All conservation aims have been fulfilled in accordance with § 36 Section 1, 1 - 3 Federal Law of the Protection of Nature. According to $\S 4$ No. 1 LSchVO, it is not permitted to "erect or extend structural works of any kind". However, an exemption may be granted if this would not compromise the conservation aim of the area or if it cannot be attenuated or adjusted by conditions or requirements (§ 4 Section 2 LSchVO Eulenkopf). If it is not possible to prove that the necessary measures of attenuation or adjustment can be provided within the proposed development, an exemption cannot be granted.

According to the current regional planning programme Westpfalz (Western Palatinate), landscape conservation areas such as "Eulenkopf and surrounding area" are among the excluded area categories. Thus they are not available for the erection of wind turbines [27]. This, however, is questioned by the Partial Adjustment of the LEP IV.

Already in 2001, consideration was given to use the conservation area as a location for wind turbines. At that time, a land owner intended to build a wind energy plant with $65 \mathrm{~m}$ hub height in the district of Sulzbach. This plan was rejected by the country care authority of the district administration Kaiserslautern. In response, the owner submitted a lawsuit to the responsible administrative court in Neustadt a.d.W. This, however, confirmed the decision of the country care authority and considered it to be inadmissible to build wind turbines in that area, because it would contradict the conservation aim and would bring about a massive intervention into the cultivated landscape of this protected area [21]. Thus, it would lead to a strong technical overprinting of the landscape, which would be mainly due to the topography of the hilltop location.

Furthermore, the verdict also points out that the erection of wind turbines within the landscape conservation area must not be automatically approved, as wind turbines which have already been erected in the boundary area of the adjacent district Rothselberg in the district of Kusel, already provide a certain pollution level [21]. It is clear that the adjacent wind turbines do not negatively affect the visual connections of the landscape conserva- 
tion area "Eulenkopf and surrounding area" due to their topographic arrangement and height. Moreover, it is not at a location which offers a lookout point from where a panoramic view is possible.

Since the proposed development contradicts the conservation aim, and no reduction, prevention or compensation of the adverse effects could be determined by constraints, the decision of the country care authority via the administrative court Neustadt a.d.W. was regarded as legitimate [21]. Furthermore, the decision points out that the projects in the outdoors may not be arbitrarily undertaken at any location, but that a continuously considerate exploitation of resources must be ensured [21]. Furthermore, there it is no atypical case of unintended hardship [21]. The only point in favour of erecting wind turbines is the public interest in using renewable energies. This, however, is not sufficient for an exemption because wind turbines are not site-specific and can be built at other locations in the outskirts, and not necessarily within the landscape conservation area [21].

In contrast, the "Rundschreiben Windenergie" (Newsletter Wind Energy), which was published in Rhineland-Palatinate in 2013, states that on one hand it is possible to grant permissions and exemptions, if it is on grounds of overriding public interest [28]. On the other hand it is determined that the necessary permission shall be reissued on a regular basis because the use of renewable energy always overrides other considerations [28]. This presents an essential contradiction, in which the "Rundschreiben Windnergie" (Newsletter Wind Energy) according to Kusche [29] does not follow the current jurisdiction.

At this point, it is not possible to interpret the judicature obviously. As a consequence, it is quite difficult, to inform the citizens and residents about the potential upcoming impacts of the development proposal.

\section{Details of the Proposed Project}

Based on the Partial Adjustment of the LEP IV, the municipalities Sulzbachtal and Frankelbach and the association of municipalities Otterbach are planning a cooperation with the JUWI AG, which already operates a number of wind turbines in Germany, in order to make new advances towards the planning of new wind turbines in the landscape conservation area "Eulenkopf and surrounding area" [29]. At the meeting of the Board of Association of Municipalities on 16 August 2013, the amendment of the land utilisation plan was initiated in order to establish legal planning requirements for the construction of wind turbines [29]. The intention was to build seven wind turbines within the municipal area of Sulzbachtal and Frankelbach with a total height of 200 meters each [22].

The three municipalities Sulzbachtal, Frankelbach and Eulenbis, all of which are located in the landscape conservation area "Eulenkopf and surrounding area", are in dispute over these proposed plans. The local authority Eulenbis is using the conservation area as a tourist destination and expresses great interest in the preservation of the landscape. The local authority of Sulzbachtal, on the other hand, can hardly benefit from its use as a tourist attraction because of its topographical location in the valley. Visitors tend to stay on the plateau of Eulenbis and therefore also mainly frequent the local gastronomy there. Thus, the municipality Sulzbachtal does not benefit but merely has to battle against the restrictions arising from the regulations of the conservation area [10]. The driving force in connection with the planning of wind turbines is represented by the mayor of Sulzbachtal, Mr. Zinsmeister, whose concern it is to diminish the indebted financial situation of his local authority. Sulzbachtal would benefit the most from the installation of wind turbines, but the local authority Erzenhausen, which also adjoins to the plateau, would also endeavour setting up wind energy plants in their district if a permit was secured.

However, the local population has mixed views towards the project. On the one hand there is the group of people that benefits from the landscape conservation area and therefore are against the setting up of wind turbines. On the other hand, supporters of the project can see no positive effect coming from the protected area or are even limited by its restrictions. Although no citizen initiatives have yet been formed, the mayor of Eulenbis, Mr. Bürgner, together with the local council, is very dedicated in his campaign against wind turbines.

In the course of fighting the construction of wind turbines, image manipulations were used to raise people's awareness of the proposed plans and to visually bring forward consequences and impacts on a previously untouched protected area. For this, maps and graphical material was used to illustrate the locations and size of the different projected wind turbines.

To expand this procedure further still, and to inform as many people as possible about the serious consequences, the University of Kaiserslautern, or more specifically the teaching and research department Physical Geography, developed a way to make this illustration available for everyone via smartphone or tablet. By means of "Augmented Reality", images with 3D models are overlaid by wind turbines. Previously, coordinates had been placed on those 3D models, in order to comprehend the planned future location as accurately as possible. 
In Augmented Reality “(...) real situations are equipped with additional digital information so that the relevant objects and items can enter into communication with computer systems. Thus, a conceptual design, generated as a computer graphic similar to a traditional photomontage, may be overlaid by inserting a real life situation. This can be done automatically by using a computer equipped with positioning technology (GPS-receiver), which executes the image overlay geometrically exact with regards to position and orientation" [30].

A clear advantage of this is the possibility that, firstly, the 3D models can be accurately assigned to the proposed locations using coordinates. Secondly, it is therefore also possible to simulate the exact height of the wind turbine and illustrate it on the screen of the mobile device.

For the simulation of this project, the application (abr.: app) "LayAR" is used, which is freely available on the platforms Android, iOS and BlackBerry. In addition, an adapted database is accessed, which was developed by the department Computer-aided Planning and Design Methods of the University of Kaiserslautern. Here coordinates are placed in a map and connected to the previously developed 3D model, which has a total height of about $200 \mathrm{~m}$ and is offered in Figure 3. Additionally, more information of the model or the project can be stored, however, this is currently irrelevant for the specified project.

This can help interested citizens, as well as political decision makers, gain an impression of the extent of the impacts such a development would have, without having to actually carry out a project.

In practice, however, this type of illustration presented some problems difficult to exert some direct influence on. For example, it became apparent that the GPS sensors and gyroscopes (tilt sensors) of different smartphone and tablet manufacturers show differing accuracies. The consequence of this was that the models were in parts not positioned at the correct, predetermined coordinates, and therefore deviated from the expected positions. It is important to ensure that the devices are calibrated before use and the view of the sky is as unobstructed as possible, so that a high number of GPS satellites can be used for position determination. The more satellites are reached, the higher is the accuracy of the location.

Furthermore, it should be mentioned that it is not yet currently possible to display the shadow of the blades within the app, which would certainly be helpful in the illustrated case. The so-called disco effect of turbines of this size would for sure play a crucial role for local residents when looking at the impact on the public interest.

Another possible measure may be a marker-based illustration of the 3D models. These so-called markers, indicated in Figure 4, must be affixed to the particular position at which a wind turbine is to be installed. The markers can be either simple photos or, for example, QR codes. By linking this marker with the 3D model, this will be illustrated as an overlay directly on-site. One problem of this method is that the 3D models of the wind turbines are about $200 \mathrm{~m}$ high and can therefore not be fully represented on a smartphone or tablet display. This is because an illustration of the model is only possible as long as the camera of the smartphone or tablet is

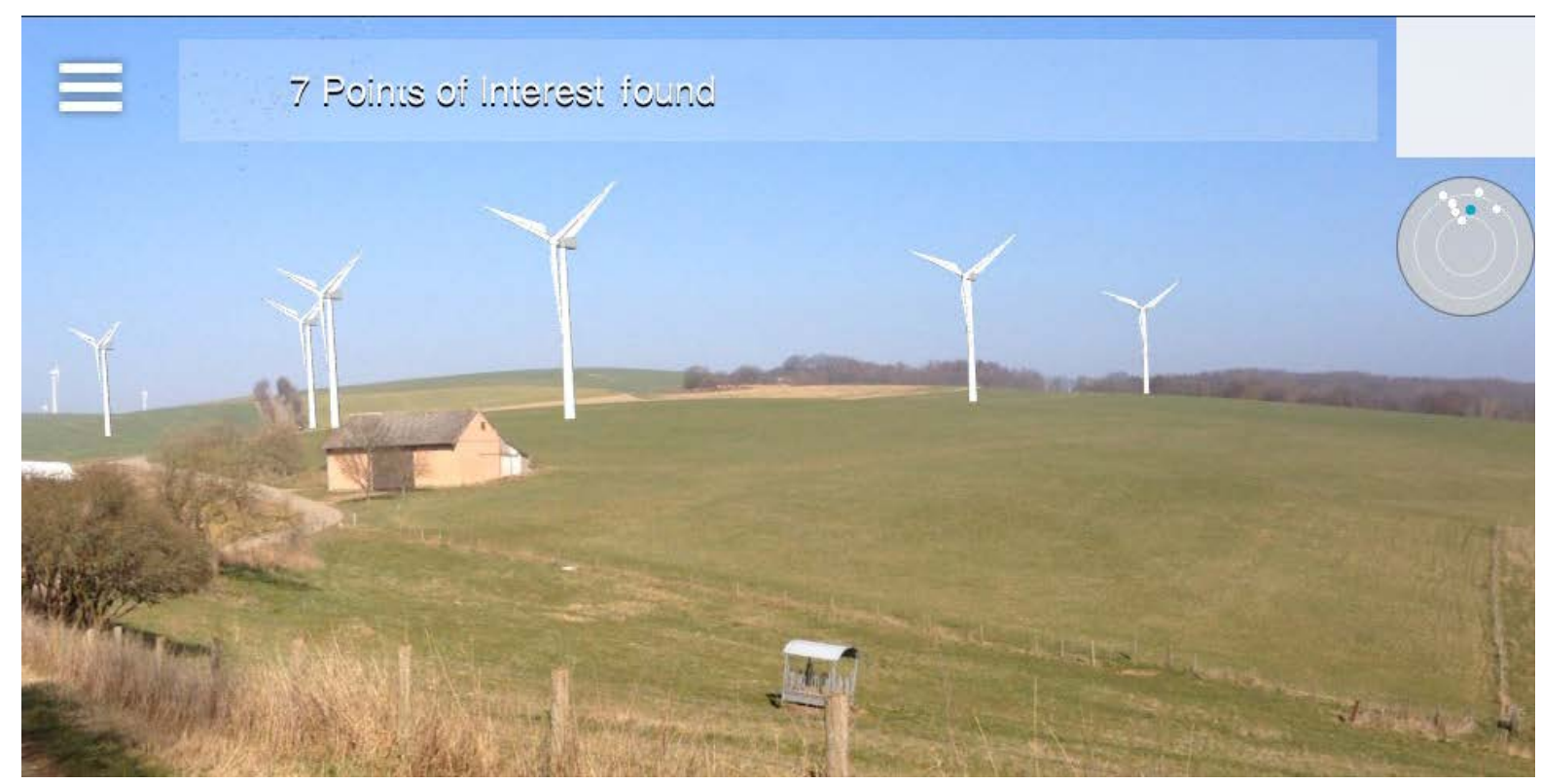

Figure 3. Illustration of the 3-dimensionally modelled wind energy plant at Eulenbis. 


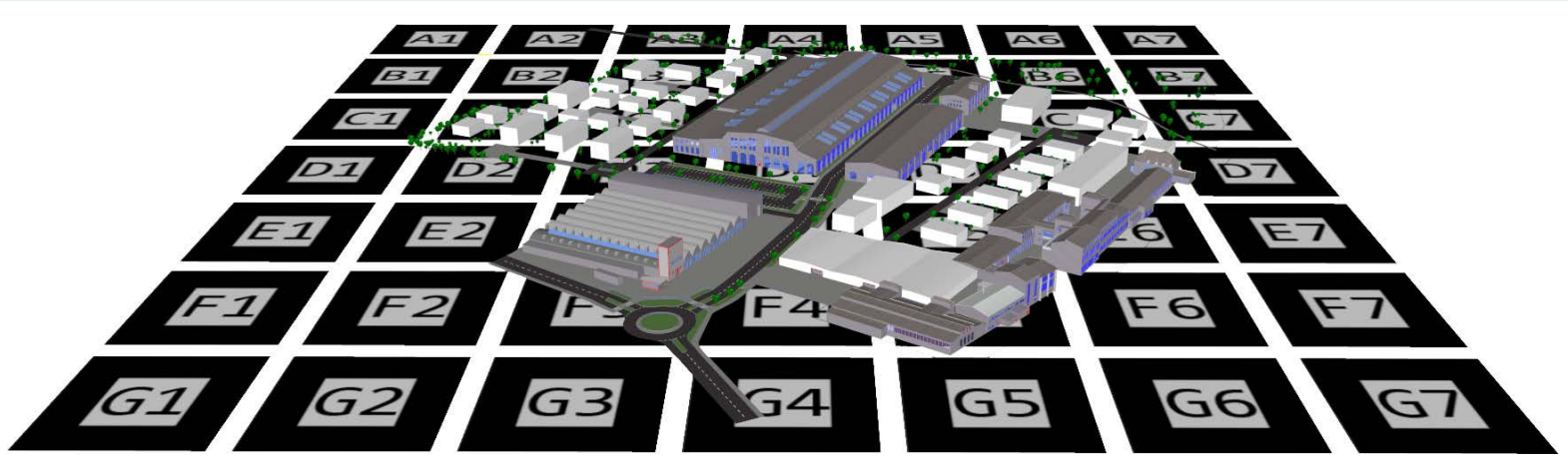

Figure 4. Illustration of a Marker Grid with a 3D-model [31].

directed at the marker. However, since one is situated directly at the location of the $200 \mathrm{~m}$ high wind turbine, a complete illustration is not possible.

It would, however, be conceivable to use this technique to develop a complete spatial 3D model of the municipality, in which house structures and roads, as well as the digital terrain model (DTM) are stored in addition to the wind turbines. If such a model was recorded on a marker, it would be possible to re-enact the overall effect on the screen of your smartphone or tablet from many different perspectives, such as the bird's eye view.

Nonetheless, this illustrated method is not resorted to, as the implementation and the development of the 3D-models is too expensive and time-consuming. In addition, no clear statement can be made as to whether any current smartphones meet the requirements and whether a correct representation of the model can be guaranteed.

According to the shown up technology, it is possible for every citizen and resident, to illustrate the planned wind turbines on the display of mobile devices that are equipped with the required application and a camera. In this way, the user gets the opportunity, to demonstrate visually the upcoming planning intentions.

\section{Project Evaluation}

The proceedings regarding the examination of the locations of wind turbines within the landscape conservation area "Eulenkopf and surrounding area", which were resumed due to the Partial Adjustment of the LEP IV, show that, despite the newly gained competencies of the communities, setting up wind turbines in protected areas remains difficult. The municipalities of Frankelbach and Sulzbachtal have so far merely initiated the adjustments in the land utilisation plan. What is still missing, however, is the request at the nature conservation authority of the district administration Kaiserslautern whether a concentration zone for the use of wind energy can be successful in the area of the landscape conservation area "Eulenkopf and surrounding area". It is important to clarify the question whether the land utilisation plan stands much chance of being approved, taking into consideration legal aspects of immissions, and whether planning in this kind of area would be possible [10]. The conservation aim of the landscape conservation area is to preserve the typical characteristics of the landscape of the "North Palatine hill country", as well as the protection of the ecosystem. Previous impacts exist through the existing facilities at the border area, at which repowering is to take place in future, which means that the level of impact on the protected area will increase further [10]. While this may be justification to release border areas of the protected area, however, there is no legal obligation to do so.

The aim of the landscape conservation area "Eulenkopf and surrounding area" is to preserve the typical character of the area [10]. The responsibility of granting permission for the erection of wind turbines within the protected area lies with the nature conservation authority of the district of Kaiserslautern. As a reference for the authority's decision in the current case, the previously mentioned verdict of the Administrative Court of Neustadt a.d.W. is cited, in which neither permission nor a waiver were granted for the project of erecting wind turbines with a hub height of $65 \mathrm{~m}$. These circumstances must now, however, be re-examined.

With regard to the exemption, however, it is to be referred to the conservation aim of the regulation. If this is in conflict with the project, no exemption shall be granted. In the event that seven 200 meter high wind turbines will be built, it can be assumed that this would lead to a technical overprinting of the landscape, which again would lead to a transformation of the cultivated landscape into a technologically shaped landscape [32]. Since the construction of wind turbines is to be implemented in the heart of the landscape conservation area, it is clear that the plans contradict the conservation aim, which in turn has the consequence that an exemption cannot be 
granted [32]. It now needs to be examined whether a waiver can be considered. According to §67 Section 1 BNatSchG, two reasons can be cited here:

1. Predominant public interest and,

2. an unreasonable burden (on an individual basis).

The existence of an unreasonable burden must be consistent with the interests of nature conservation in order to be worth a waiver. However, Dein certified that this is no atypical case of unintended hardship [32]. In the present case, the harshness that leads to the exclusion of the proposed plans is intended. This ensures that the regulations of the protected area continue to fulfil its purpose. Public interest in the construction of wind turbines is indeed given, but it must be balanced with other interests and thus cannot as a rule lead to a waiver. Otherwise, the procedure must be declared as illegitimate, as the decision of the legislative body would be administratively overridden [32]. Furthermore, granting a waiver must not lead to the landscape protection regulation (LSchVO) to become inoperable.

As it can currently not be assumed that an exemption or a waiver will be granted, a partial or full cancellation of the regulations of the protected area is seen as a last chance to revise planning of the protected area [32]. After the construction of wind turbines, the regulations would no longer be applicable, also in view of restriction of the past for other uses. A partial abolition is discarded in the present case, as the major part of the protected area surrounding the Eulenkopf is affected. In the case of a full revocation of the landscape conservation area status, the designation needs to be examined by applying the same criteria from the opposite viewpoint. A conservation aim does not need to exist. The discretion lies with the regulatory authority [10].

Thus it needs to be determined that the legal situation regarding the application of the regulation of the landscape conservation area "Eulenkopf and surrounding area" does not change because of the Partial Adjustment of the LEP IV. Wind turbines are not permitted in this area, as the construction is in opposition to the conservation aim. This would have a potentially negative impact on the landscape. The wind turbines are contrary to the conservation aim to preserve the distinctive and diverse landscape, as well as to the protection of general nature-orientated recreation ( 33 Section 1a and c LSchVO Eulenkopf). A panoramic view is greatly disturbed by the construction of wind turbines, and lookout points with a good view into the far distance will lose their attraction for recreation seekers. Therefore, the compatibility of wind turbines within the core area of the protected area is to be classed as very low, as a deterioration of the circumstances is to be expected.

To date, the area does not exhibit any zoning, thus the conservation aims apply area-wide. In principle, by changing the protected area regulations, zoning, which allows implementing wind turbines in the predisposed border areas of the protected area, would indeed be conceivable. However it would be appropriate to aspire to attain an exemption for the entire protected area, as the conservation area is relatively small in size. The construction of wind turbines in the core of the area would lead to a significant deterioration of the landscape and could potentially result in the loss of its status being worthy of protection as well as its unique features. Furthermore, the wind speeds within the area are even below the economic limit, meaning that the location cannot be classed as particularly suitable. The Partial Adjustment of the LEP IV stipulates that especially areas with good wind conditions are to be given priority, which is not met in the landscape conservation area "Eulenkopf and surrounding area". Moreover, wind turbines are not tied to a location, thus excess planning of the protected area is not imperative, as there are plenty of areas in the district of Kaiserslautern, which are outside the protected area and exhibit good enough wind conditions. These areas should therefore be favourably considered for the use of wind energy.

Should the JUWI AG, as well as the surrounding municipalities of Sulzbachtal and Frankelbach, still wish to proceed with their plans, it will be in their duty to provide citizens with enough information about the consequences of the construction of wind turbines, and to raise their awareness so that they gain an impression of what an implementation of wind turbines would mean for the landscape conservation area "Eulenkopf and surrounding area". Although it is on the one hand understandable that, due to their financial situation, local authorities need to balance their budgets and improve their economic outlook, but on the other hand neither nature itself nor affected citizens should be excluded from this decision.

Using the illustration of the proposed wind turbines in the form of 3D models, it is possible to provide laymen with a tool which allows them to gain a better idea of the proposed plans, which, above all, aims to expand the conventional type of comprehensive plans with an additional illustration method. For this, no explicit expert knowledge is necessary in order to get one's bearings on maps or plans, and to understand proposed plans. Rather, it can even be simulated right on-site, where future plans of wind turbines are to be implemented. 
Due to the demonstrated legal position, it is actually fairly difficult, to make a prediction concerning about the planning purposes. It indicates that the Partial Adjustment of the State Development Programme IV (LEP IV) will still be opposed to a great number of legal obstacles, whereby a contemporary execution of the project is hard to imagine.

\section{References}

[1] Fest, P. (2010) Die Errichtung von Windenergieanlagen in Deutschland in seiner ausschließlichen WirtschaftszoneGenehmigungsverfahren, planerische Steuerung und Rechtsschutz an Land und auf See, Duncker \& Humblot, Berlin.

[2] Scheidler, A. (2011) Errichtung von Windkraftanlagen in naturschutzrechtlich festgesetzten Schutzgebieten. Natur und Recht, 12, 848-856. http://dx.doi.org/10.1007/s10357-011-2182-z

[3] Braune, T. and Ismar, G. (2011) Schwarz-Gelb beschließt Atomausstieg bis 2022. http://www.welt.de/politik/article13401638/Schwarz-Gelb-beschliesst-Atomausstieg-bis-2022.html

[4] Ministerium für Wirtschaft, Klimaschutz, Energie und Landesplanung, Ministerium für Finanzen, Ministerium für Umwelt, Landwirtschaft, Ernährung, Weinbau und Forsten, Ministerium des Innern, für Sport und Infrastruktur Rheinland-Pfalz (2013) Hinweise für die Beurteilung der Zulässigkeit der Errichtung von Windenergieanlagen in Rheinland-Pfalz (Rundschreiben Windenergie), Mainz.

[5] Ministerium für Wirtschaft, Klimaschutz, Energie und Landesplanung Rheinland-Pfalz (2013) Windatlas RheinlandPfalz, Mainz.

[6] Fischer-Hüftle, P. (2012) Windenergieanlagen und Landschaftsschutz. Bayerische Verwaltungsblätter, 23, 709-715.

[7] Spannowsky, W. and Hofmeister, A. (2012) Naturschutzgerechte Steuerung der Windenergienutzung durch die gesamträumliche Planung. Lexxion Verlag, Berlin.

[8] Fischer-Hüftle, P. (2003) §26 Landschaftsschutzgebiete. In: Schumacher, J. and Fischer-Hüftle, P., Eds., Bundesnaturschutzgesetz Kommentar,Kohlhammer-Verlag, Stuttgart, 412-425.

[9] Heugel, M. (2010) §26 Landschaftsschutzgebiete. In: Lütkes, S. and Ewer, W., Eds., Bundesnaturschutzgesetz Kommentar, C. H. Beck, München, 293-297.

[10] Langenbahn, E. and von der Au, L. (2014) Analyse der Teilfortschreibung Erneuerbare Energien des LEP IV in Rheinland-Pfalz hinsichtlich naturschutzfachlicher sowie, rechtlicher Konflikte bei der planerischen Steuerung von Windenergieanlagen anhand ausgewählter Beispiele. Master Thesis, University of Kaiserslautern, Kaiserslautern.

[11] Federal Agency for Nature Conservation (2010) Bundesnaturschutzgesetz. http://www.gesetze-im-internet.de/bnatschg 2009/index.html

[12] Scheidler, A. (2012) Windräder in Natura 2000-Gebieten? Deutsches Verwaltungsblatt, 4, 217-221.

[13] Thyssen, B. (2011) Rückenwind? Bewältigung der Herausforderungen in Genehmigungsverfahren zum Ausbau der Windenergie. Zeitschrift für Immissionsschutzrecht und Emissionshandel I + E, 2011, 134-145.

[14] Nohl, W. (2010) Landschaftsästhetische Auswirkungen von Windkraftanlagen. Schönere Heimat, 2010, 3-12.

[15] Barth, S., Baumeister, H. and Schreiber, M. (1997) Leitfaden für die kommunale Planung unter besonderer Berücksichtigung von Naturschutzbelangen. Rhombos-Verlag, Berlin.

[16] Greiving, S. and Schröder, M. (2003) Neue Herausforderungen bei der planerischen Steuerung von WEA. Umwelt und Planungsrecht, 2003, 13-17.

[17] Attendorn, T. (2013) Berücksichtigung der Belange der Energiewende bei der Anwendung des Naturschutzrechts. Natur und Recht, 35, 153-262. http://dx.doi.org/10.1007/s10357-013-2415-4

[18] Kühnau, C., Reinke M., Blum, P. and Brunnhuber, M. (2013) Standortfindung für Windkraftanlagen im Naturpark Altmühltal. Erstellung eines Zonierungskonzepts. Naturschutz und Landschaftsplanung, 45, 271-278.

[19] Landschaftsinformationssystem der Naturschutzverwaltung Rheinland-Pfalz (2014) Verordnung über das Landschaftsschutzgebiet "Eulenkopf und Umgebung” vom 30. August 1977. http://www.naturschutz.rlp.de/dokumente/rvo/lsg/07-LSG-7335-010.pdf

[20] LANIS Rheinland-Pfalz (2014) Landschaftsschutzinformationssystem der Naturschutzverwaltung, Rheinland-Pfalz. http://map1.naturschutz.rlp.de/mapserver_lanis

[21] Administrative Court Neustadt an der Weinstrasse (2001) Verdict of 24. September 2001, Reference No. 4K2104/00. N.W.

[22] Die Rheinpfalz (2012) Wieso mit 10,000 Euro zufriedengeben. 320, 14.

[23] Association of Municipalities Weilerbach (2014) Ortsgemeinde Eulenbis. http://www.weilerbach.de/ortsgemeinden/eulenbis/index.html 
[24] Die Gemeindeverwaltung in Rheinland-Pfalz (2013) Nordwesten von Rheinland-Pfalz bei erneuerbaren Energien vorn. Windkraft vor Fotovoltaik-Überragende Bedeutung des ländlichen Raums. Die Gemeindeverwaltung in RheinlandPfalz, 9, 252-256.

[25] Ministry of Economic Affairs, Climate Protection, Energy and Land Use Planning Rhineland-Palatinate (2013) Windatlas Rheinland-Pfalz, Mainz.

[26] Ministry of Economic Affairs, Climate Protection, Energy and Land Use Planning Rhineland-Palatinate (2014) Windatlas Rheinland-Pfalz. http://www.windatlas.rlp.de/windatlas/

[27] Planning Association Westpfalz (2013) Westpfalz-Informationen-Potentialrechner Erneuerbare Energien fpü die Region Westpfalz, Wie viel Strom aus Erneuerbaren Energien kann in der Region Westpfalz erzeugt werder? Ein Leitfaden für Landkreise, kreisfreie Städte und Kommunen.

[28] Ministry of Economic Affairs, Climate Protection, Energyand Land Use Planning; Ministry of Finance, Ministry of the Environment, Rural Affairs, Food, Vinicultureand Forestry, Ministry of theInterior, Sport and Infrastructure Rhineland-Palatinate (2013) Hinweise für die Beurteilung der Zulässigkeit der Errichtung von Windenergieanlagen in Rheinland-Pfalz (Rundschreiben Windenergie), Mainz.

[29] Kusche, K.L. (2013) Errichtung von Windenergieanlagen im Landschaftsschutzgebiet Eulenkopf, Beschlussvorlage. Kreisverwaltung Kaiserslautern, 11-14.

[30] Streich, B. (2011) Stadtplanung in der Wissensgesellschaft-Ein Handbuch. VS-Verlag, Wiesbaden. http://dx.doi.org/10.1007/978-3-531-93164-7

[31] Noll, R. (2012) Der Einsatz von Augmented Reality Methoden zur Kommunikation bei Konversionsprojekten. Bachelor Thesis, University of Kaiserslautern, Kaiserslautern.

[32] Dein, A. (2012) Windkraft-Planung im Landschaftsschutzgebiet, Eulenkopf und Umgebung. Rechtliche und fachliche Aspekte.Niederschrift der 26. Sitzung des Kreistages vom 12.11.2012, 56-71. 
Scientific Research Publishing (SCIRP) is one of the largest Open Access journal publishers. It is currently publishing more than 200 open access, online, peer-reviewed journals covering a wide range of academic disciplines. SCIRP serves the worldwide academic communities and contributes to the progress and application of science with its publication.

Other selected journals from SCIRP are listed as below. Submit your manuscript to us via either submit@scirp.org or Online Submission Portal.
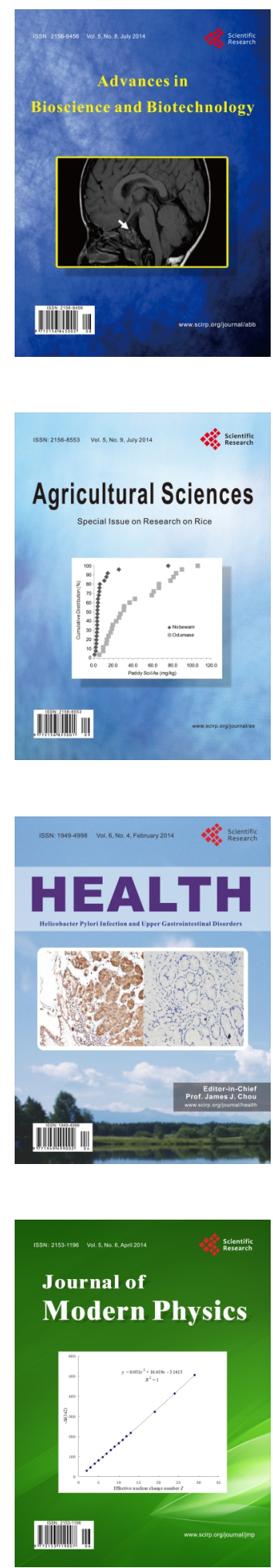
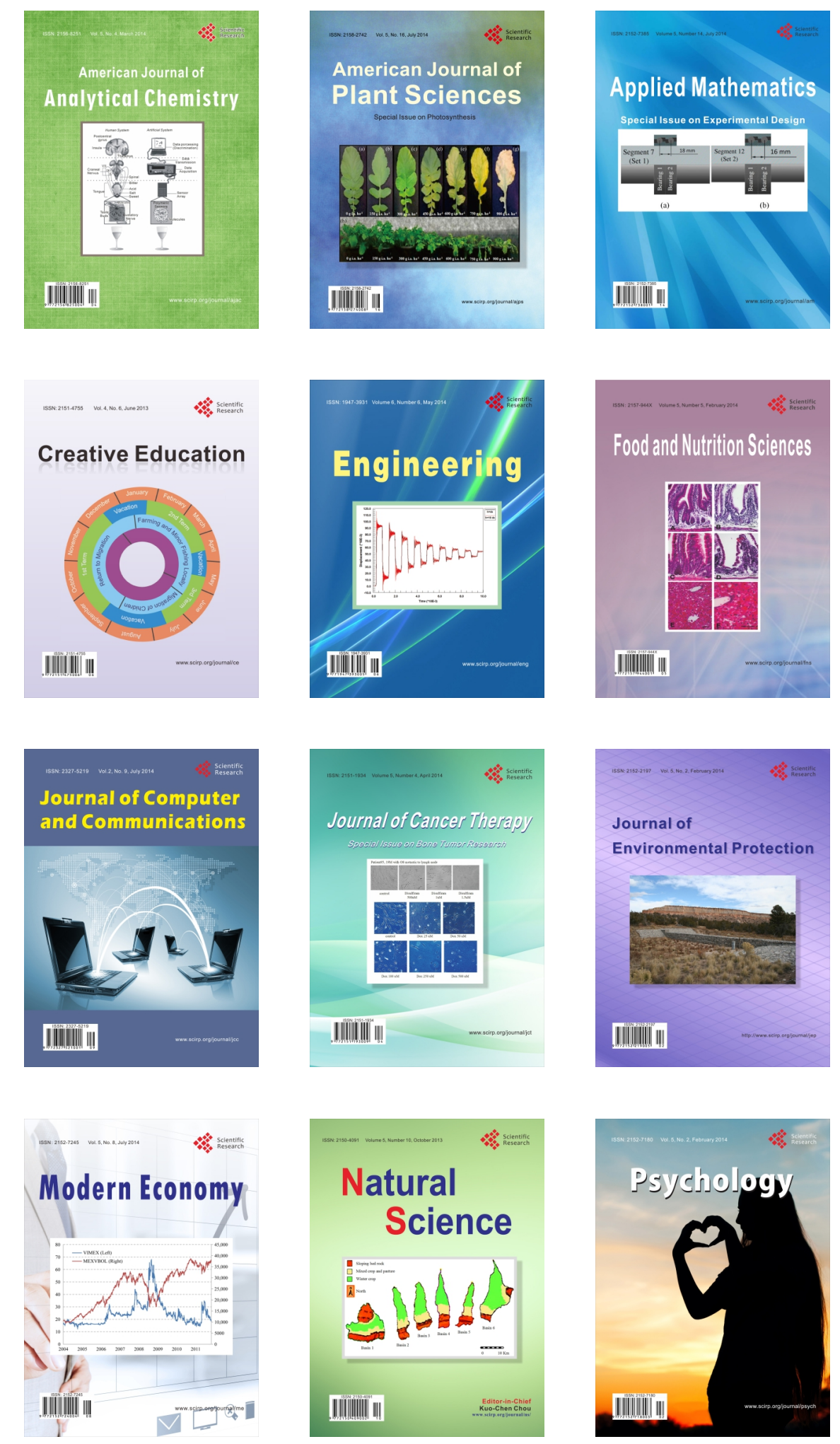